Sains Malaysiana 49(12)(2020): 3089-3095

http://dx.doi.org/10.17576/jsm-2020-4912-21

\title{
Influence of Multilayer Al-Doped ZnO Thin Film on Photocatalytic Degradation of Methyl Blue
}

\author{
(Pengaruh Filem Nipis ZnO Terdop-Al Berbilang Lapis pada Degradasi Fotokatalitik Metil Biru)
}

\author{
LisZUlFAH RoZA*, ViVi FAUZIA \& MOHD. YUSRi ABD. RAHMAN
}

\begin{abstract}
The present work is focused on the photocatalytic activities of Al-doped $\mathrm{ZnO}$ sample deposited with different layers on glass substrate. The Al-doped ZnO sample was prepared via simple and cost effectiveness chemical precipitation method with addition of $5 \mathrm{wt} . \%$ of Aluminum chloride as dopant. All materials were dissolved in mixture of $45 \mathrm{~mL}$ ethylene glycol and $15 \mathrm{~mL}$ deionized water while the growth process was carried out at temperature $200{ }^{\circ} \mathrm{C}$ for 30 min assisted with stirring process at $550 \mathrm{rpm}$ using hotplate. The precipitated of as prepared sample were deposited with different layers on glass substrate using spin coating process. The samples were characterized by UV-Vis spectrophotometer, Raman spectroscopy, and photoluminescence to investigate the optical properties and crystal structure of ZnO sample. In particular, according to UV-Vis the absorption spectra of the sample significantly increase as the number of layers increase. Meanwhile, Raman and photoluminescence analysis indicate that the sample contains lots of structural defect as a result of the incorporation of ion Al into $\mathrm{ZnO}$ lattice. The photocatalytic activity of Al-doped $\mathrm{ZnO}$ thin film with different layers was evaluated in degradation of methyl blue solution under UV light illumination. The best photocatalytic activity was observed from 6 layers of Al-doped $\mathrm{ZnO}$ thin film within 45 min of exposure to UV light illumination. This study may open a versatile route to achieving high efficiency of photocatalytic activity of ZnO.
\end{abstract}

Keywords: Al-doped ZnO; methyl blue; optical properties; photocatalyst

ABSTRAK

Fokus kajian ini adalah pada aktiviti fotokatalitik sampel ZnO terdop-Al yang diendap dengan lapisan berbeza pada substrat kaca. Sampel ZnO terdop-Al dihasilkan melalui kaedah pemendakan kimia yang mudah serta keberkesanan dari segi kos dengan penambahan $5 \%$ bt. aluminium klorida sebagai bahan dop. Semua bahan dilarutkan di dalam campuran $45 \mathrm{~mL}$ etilena glikol dan $15 \mathrm{~mL}$ air ternyahion sementara proses pertumbuhan dilakukan pada suhu 200 ${ }^{\circ} \mathrm{C}$ selama $30 \mathrm{~min}$ dibantu dengan proses pengacauan pada kelajuan $550 \mathrm{rpm}$ menggunakan plat pemanas. Sampel termendap telah diendapkan dengan lapisan berbeza pada substrat kaca menggunakan proses salutan putar. Sampel dicirikan oleh spektrofotometer UV-Vis, spektroskopi Raman dan fotoluminesens untuk mengkaji sifat optik dan struktur kristal sampel ZnO. Menurut hasil UV-Vis, spektrum penyerapan sampel menunjukkan peningkatan ketara apabila bilangan lapisan meningkat. Sementara itu, analisis Raman dan fotoluminesens menunjukkan bahawa sampel mengandungi banyak kecacatan struktur akibat penggabungan ion Al ke dalam kekisi ZnO. Aktiviti fotokatalitik filem nipis $\mathrm{ZnO}$ terdop-Al dengan lapisan yang berbeza dinilai berdasarkan degradasi larutan metil biru di bawah pencahayaan sinar UV. Aktiviti fotokatalitik terbaik diperhatikan dengan menggunakan 6 lapisan filem nipis ZnO terdop-Al dalam masa 45 min selepas pencahayaan sinar UV. Kajian ini dapat membuka jalan serba boleh untuk mencapai aktiviti fotokatalitik ZnO yang berkecekapan tinggi.

Kata kunci: Fotokatalis; metil biru; sifat optik; ZnO terdop-Al

\section{INTRODUCTION}

The progress of textile industry significantly has a positive impact to the economy matters due to the increasing of the opportunity to find jobs. On the other hand, it also has a negative impact on the environment because industrial development will be proportional to the production of pollutant. For example, the textile industry will produce liquid waste that come from the used dyes. Synthetic dyes that are widely used in the textile industry are methyl orange and methylene blue which commonly known as non-biodegradable, toxic, and stable organic compound that difficult to degrade naturally by decomposing process 
using bacteria or through heating process (Arifin et al. 2019). Dyestuffs provide the most extensive impact on environmental pollution because it directly reduces the aesthetic value of the aquatic environment and adversely affects to organism around the waters. Furthermore, high concentration of colour waste will prevent sunlight from directly penetrating into the waters, then it interferes in the photosynthesis process of plant in the waters. Serious hazards can arise if the toxic chromophore azo compounds which are bound to the benzene group in the dye waste accumulate in the body, causing impaired liver, and kidney function (Palit 2019).

The alternative technologies which commonly used to decompose organic pollutant in environmental are coagulation, flocculation, and adsorption techniques with activated carbon (Gusain et al. 2020). However, these techniques only convert that dye stuff from the liquid phase into the solid phase rather than decompose the chemical bonding of the dye. Furthermore, the remaining solid phase need to be further treated until safe to release into the environmental. Photodegradation using semiconductor become an alternative method that is currently widely used in waste water treatment. This method is practical and economical with high oxidation power to degrade the organic pollutant into mineralization level (Roza et al. 2020). Furthermore, photocatalytic became an advance technique which able to degraded toxic organic and inorganic compounds and bacteria in waste water (Nasrollahzadeh et al. 2021).

Zinc oxide $(\mathrm{ZnO})$ was found frequently used as a photocatalyst to degrade organic pollutant. This is due to its attractive characteristic such as high quantum efficiency, excellent mechanical characteristics, chemical and thermal stability, high photosensitivity, inexpensive, and easy to synthesis with controllable morphology, non-toxic and environmental safety (Roza et al. 2015). However, the application of pristine $\mathrm{ZnO}$ as a photocatalyst has limitations in absorbing the substances that will be degraded due to their fast recombination rate of photoexcitation of charge carriers in $\mathrm{ZnO}$. Besides, photo corrosion during the photocatalytic process limits their performance to degrade organic pollutant. The most common approach to overcome this problem is to modify the surface or their crystal defects via doping with rareearth metal, noble metal, transition metal or non-metal (Ahmad 2020). Each dopant was found to having specific characteristic to modify $\mathrm{ZnO}$ crystal lattices. For example, $\mathrm{Al}$ metal can be used as dopant in $\mathrm{ZnO}$ since $\mathrm{Al}$ has high transparency and conductivity properties (Bhujbal et al. 2020).

The aim of the present work was to synthesize Al doped $\mathrm{ZnO}$ thin films using a cost-efficient chemical precipitation method assisted with spin coating technique to deposited
$\mathrm{ZnO}$ sample onto glass substrate. Furthermore, study the influence on the number of layer Al-doped $\mathrm{ZnO}$ thin film on their optical properties, crystal structure and photocatalytic activity of $\mathrm{ZnO}$ sample. According to literature, that $\mathrm{ZnO}$ films do not easily grow well when the film thickness is thin which ended to the mismatching of crystal lattice of $\mathrm{ZnO}$ with the substrate. As the film thickness increases, the mismatching effect between the glass substrate and the $\mathrm{ZnO}$ lattice decreases. Hence, the crystallization of $\mathrm{ZnO}$ increases. Therefore, the incorporation of $5 \mathrm{wt}$. \% Al dopant and the number of layers $\mathrm{ZnO}$ sample deposited on glass substrate on the crystals structural, optical properties, and photocatalytic activity of $\mathrm{ZnO}$ is needed to explore due to its credentials on the environment cleaning applications. To assess the photocatalytic activity, the UV assisted photodegradation of methylene blue (MB) was studied. It was observed that Al-dopant significantly improves the photocatalytic activity of the $\mathrm{ZnO}$ thin film. The increase of optical absorption in UV light spectrum increase the number of layers $\mathrm{ZnO}$ sample responsible for the improvement of the observed photocatalytic efficiency.

\section{EXPERIMENTAL DETAILS}

Aluminium-doped $\mathrm{ZnO}$ powder was synthesized using wet chemical technique through heating process in hot plate and then the dispersed solution was deposited by spin coating technique onto a glass substrate. Initially Al-doped $\mathrm{ZnO}$ powder prepared by dissolving $1 \mathrm{~g}$ of $\mathrm{Zn}\left(\mathrm{CH}_{3} \mathrm{COO}\right) \cdot 2 \mathrm{H}_{2} \mathrm{O}$ and $0.0165 \mathrm{~g}$ of $\mathrm{AlCl}_{3} \cdot 6 \mathrm{H}_{2} \mathrm{O}$ into solution that contain $45 \mathrm{~mL}$ ethylene glycol and $15 \mathrm{~mL}$ deionized water. The solution was magnetically stirred and after $10 \mathrm{~min}$ stirring, the precursor solution was heated at temperature $200{ }^{\circ} \mathrm{C}$ for 30 min assisted with stirring process at $550 \mathrm{rpm}$ using hotplate until the solution become an opaque suspension. After that, the solution cooled to room temperature and the powder was collected by centrifuging at $4500 \mathrm{rpm}$ for $20 \mathrm{~min}$ and was washed several times with ethanol. The powder then dispersed in $10 \mathrm{~mL}$ of methanol and sonicated for $15 \mathrm{~min}$ using an ultrasonic cleaner. Lastly, the Al-doped $\mathrm{ZnO}$ thin film was deposited onto glass substrate by spin coating process that dispersed the solution at $1000 \mathrm{rpm}$ speed. The sample was then dried using slow evaporation process. These procedures were repeated with different layers namely 2 , 4,6 , and 8 . The sample was annealed in hotplate at 450 ${ }^{\circ} \mathrm{C}$ for $1 \mathrm{~h}$.

The characterizations have been conducted to explore the properties of Al-doped $\mathrm{ZnO}$ thin film. The surface morphology of the sample was investigated using a field emission scanning electron microscopy (FESEM Hitachi SU-8030). The optical absorption spectra was obtained using UV-Vis spectrophotometer (Thermo 
Fisher Scientific GENESYS10S) and photoluminescence spectroscopy (Edinburgh FLS 920 with $325 \mathrm{~nm} \mathrm{He}-$ Cd laser). The photocatalytic activity of sample was measured through the photodegradation of methyl blue (MB) solution as dye model. The sample were suspended in a $10 \mathrm{~mL} 10 \mathrm{mM} \mathrm{MB}$ aqueous solution and then to establish the adsorption-desorption equilibrium; the MB solution was magnetically stirred in dark for 60 min prior to the irradiation by a $40 \mathrm{~W}$ UV light. The photocatalytic experiment was carried out at room temperature in a glass beaker and the UV light source was kept $25 \mathrm{~cm}$ above the beaker. The decrease in absorption intensity of MB solution was observed using UV-Vis spectrophotometer at certain time.

\section{RESULTS AND DISCUSSION}

Figure 1 shows the optical absorption spectra of Aldoped $\mathrm{ZnO}$ thin film in the range of 300 to $900 \mathrm{~nm}$. As expected, the absorption spectra of the sample showed a strong absorption spectrum in UV light spectrum. This behavior is associated to the intrinsic nature of wide bandgap $\mathrm{ZnO}$ semiconductors (Roza et al. 2020). It was observed that the absorption spectra of the sample in UV light spectrum is significantly increased as the number of layers increased. It is confirmed that sample is effective to absorbs more light in UV light region (Rahman et al. 2015). The results peaks are comparable with the previous study and approve the formation of $\mathrm{ZnO}$ nanostructure. Furthermore, it is important to note that the absorption spectra of the sample in UV light spectrum are identical.

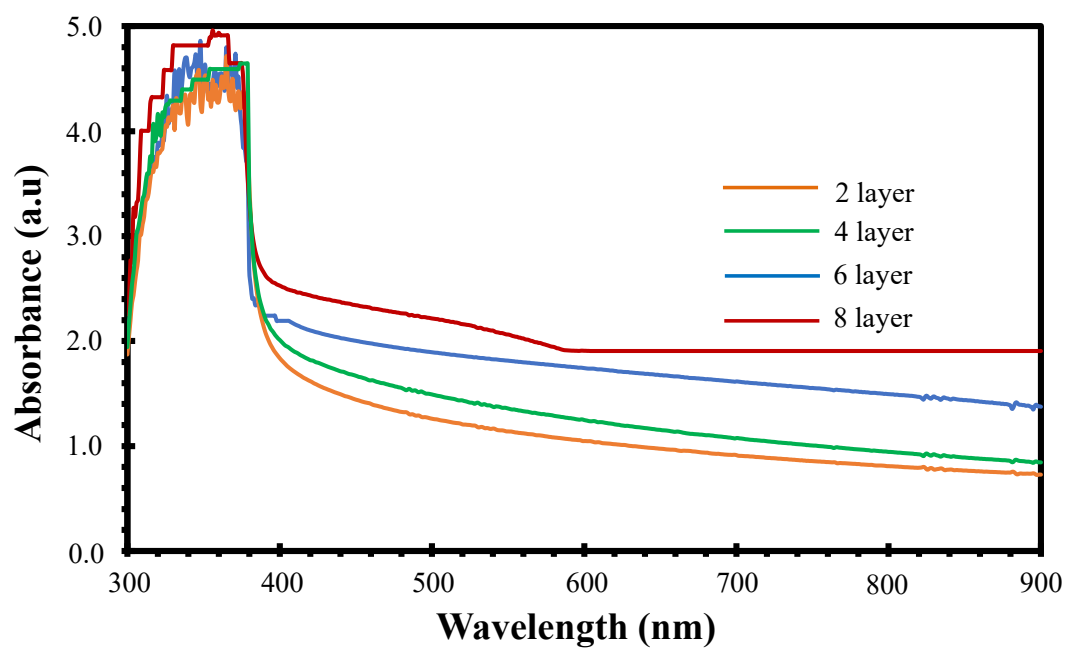

FIGURE 1. UV-Vis optical absorption spectra of Al-doped $\mathrm{ZnO}$ nanoparticle with various layer

Figure 2 shows the room temperature photoluminescence spectra of Al-doped $\mathrm{ZnO}$ thin film with different number of layers. The PL spectra of all $\mathrm{ZnO}$ sample produce similar characteristic with the existence of UV emission peak at $389 \mathrm{~nm}$, blue luminescence band approximately at $465 \mathrm{~nm}$, orange emission peak at 605 $\mathrm{nm}$ and red emission in the range between $650-800 \mathrm{~nm}$. The emissions band at UV light region corresponding to the emission peaks from radiative from donor-acceptor transition in $\mathrm{ZnO}$. This emission is commonly called near band edge emission (NBE) (Putri et al. 2018). As the number of layers increase, the intensity of Pl spectra exhibits increasing trend. This result indicated the crystallinity and optical properties of sample becomes improved. It has been well recognized that NBE emission intensity is closely corelated to the crystal quality of $\mathrm{ZnO}$ sample (Vanitha et al. 2018).

Moreover, the extensive and intense emission band at the wavelength $620-800 \mathrm{~nm}$ is corresponding to the recombination process of exciton from structural defect in $\mathrm{ZnO}$ lattice either donated by oxygen vacancies or formation of interstitial zinc. The emission peak at these wavelength is commonly called deep level emission (DLE) (Bora et al. 2017). The sample with 6 layers possesses the most intense emission luminescence in visible light spectrum which indicates the sample contain lots of structural defect and excess oxygen site on their surface (Roza et al. 2016). Meanwhile, the sample prepared with 2 layers show the lowest emission peaks which specifies that sample having lower structural defect. It 
was reported that $\mathrm{ZnO}$ sample with rich concentration of oxygen vacancies are advantage for photocatalytic activity of $\mathrm{ZnO}$. The same observation was reported by Wang et al. (2020).

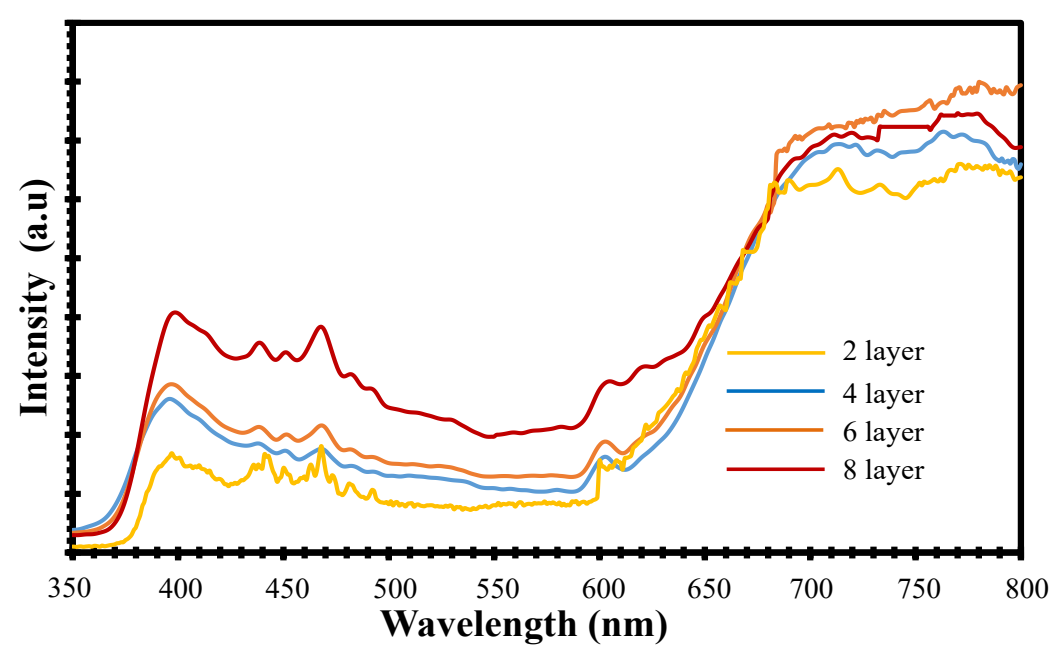

FIGURE 2. Photoluminescence spectra of $\mathrm{Al}$ doped $\mathrm{ZnO}$ thin film with various layer

Figure 3 shows the room temperature Raman spectra of Al-doped $\mathrm{ZnO}$. The Raman spectra $\mathrm{ZnO}$ sample exhibit five modes at 90.56, 579.13, 1085.21, 1518.25 and $2498.28 \mathrm{~cm}^{-1}$, respectively. These modes are associated to the fundamental photon mode of hexagonal $\mathrm{ZnO}$. The peak at $90.56 \mathrm{~cm}^{-1}$ is commonly attributed to E2L mode of wurtzite $\mathrm{ZnO}$ and the vibration of $\mathrm{Zn}$ sub-lattices. High intensity at this peak indicated high crystal quantity of the sample (Doan et al. 2020). Meanwhile, the high peak intensity located at $579.13 \mathrm{~cm}^{-1}$ correspond to the overlap of two peaks reference to the E1 (LO) and $\mathrm{A}_{1}(\mathrm{LO})$ phonon mode. These phonon modes are low frequency non-polar mode which are very sensitive to crystal defects or impurities such as oxygen vacancies or interstitial zinc in $\mathrm{ZnO}$ lattice. This result confirmed that sample contains numerous amounts of structural defect on their surface, especially oxygen vacancies. This result is in good agreement with the PL analysis. Furthermore, the peak located at $1085.21,1518.25$, and $2498.28 \mathrm{~cm}^{-1}$ are attributed to the second order (2LO) Raman mode and associated to the $\mathrm{A}_{1}$ and $\mathrm{E}_{1}$ acoustic combination symmetry modes (Mao et al. 2020).

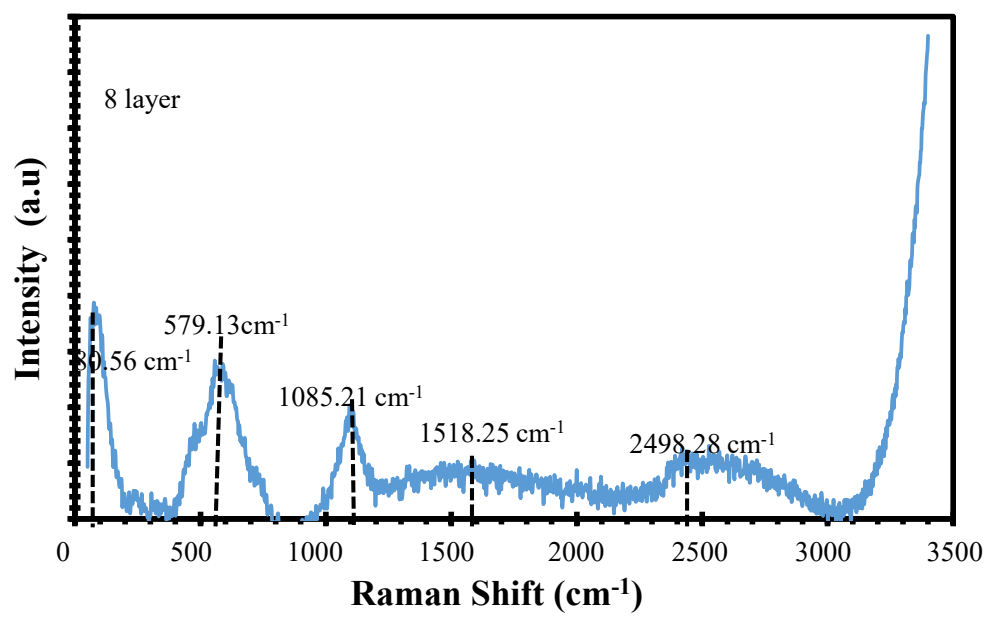

FIGURE 3. Raman spectra of Al-doped $\mathrm{ZnO}$ thin film deposited with 6 layers 
Photocatalytic activity of the Al-doped $\mathrm{ZnO}$ thin films with various layers were examined through the degradation of methyl blue (MB) under ultraviolet (UV) illuminations. The photocatalytic rate of decolorization MB solution was achieved by monitoring the corresponding deviations in the intensity of the absorbance peak wavelength at $596 \mathrm{~nm}$ at regular time interval. The difference in the absorption intensity of MB solution with and without Al-doped $\mathrm{ZnO}$ thin film photocatalyst at different irradiation times is recorded and presented in Figure 4. As shown in Figure 4, it was observed that the absorption intensity of $\mathrm{MB}$ solution more quickly decreased with the presence of Al-doped $\mathrm{ZnO}$ photocatalysts. This result showed that $\mathrm{ZnO}$ sample is active and efficient in degrading the MB solution.
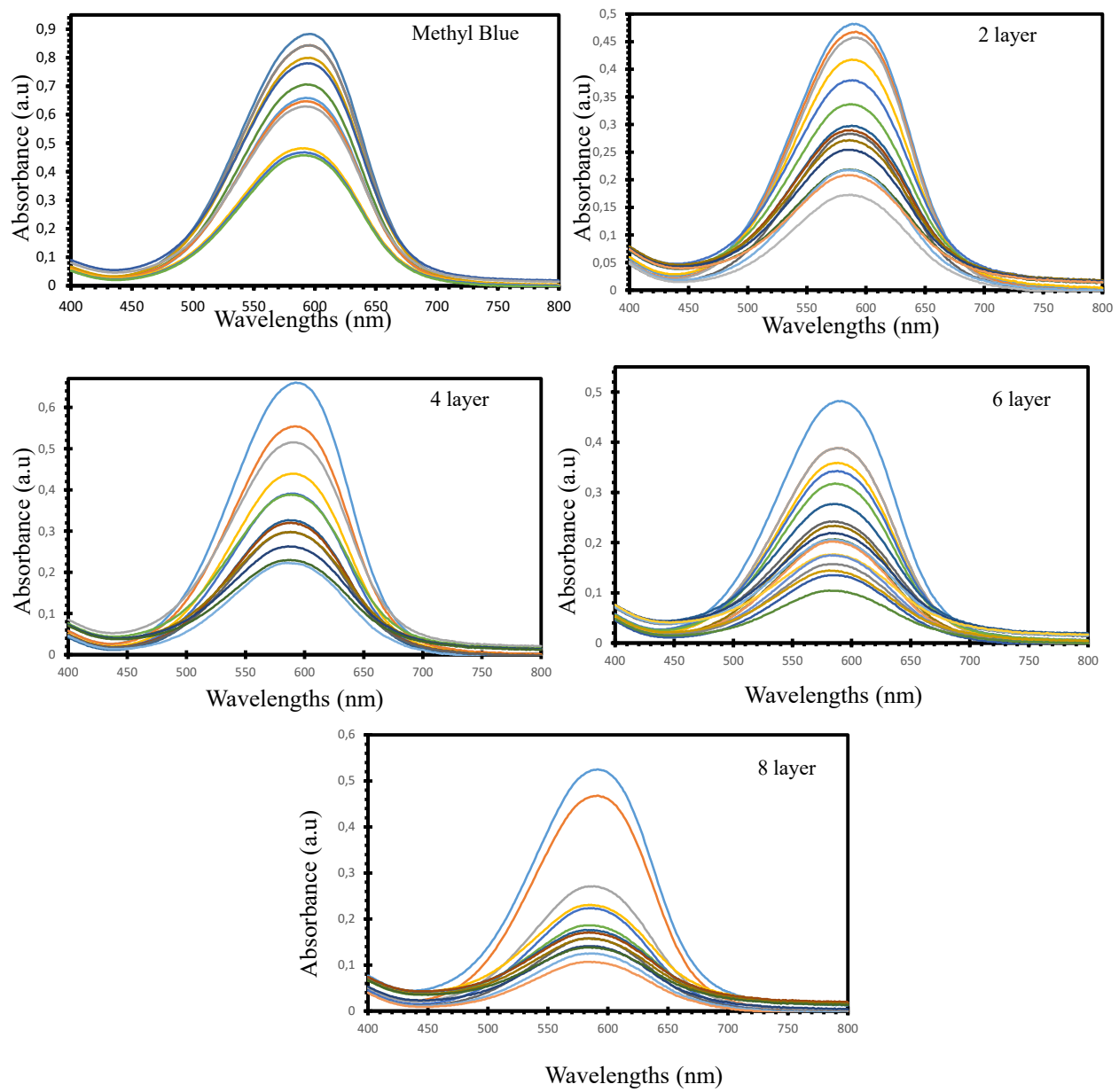

FIGURE 4. Absorbance spectra of methyl blue (a) without the Aldoped $\mathrm{ZnO}$ photocatalyst with various layers

The photocatalytic degradation efficiency of Aldoped $\mathrm{ZnO}$ thin films with different number of layers are presented in Figure 5. The photocatalytic degradation efficiency of methyl blue solution under UV light illumination without $\mathrm{ZnO}$ sample has reach $19 \%$. Meanwhile, the degradation efficiency of methyl blue solution in the presence of Al-doped $\mathrm{ZnO}$ photocatalyst
2, 4, 6, and 8 layers are $63.10,70.7,79.9$, and $73.4 \%$, respectively. The photodegradation efficiency of our sample with photodegradation efficiency up to $\sim 79.9 \%$ is much higher than the result reported by Ben Ameur et al. (2019) with the photodegradation efficiency less than $50 \%$ to decomposed methyl blue solution under illumination of UV light at the same time period ( $45 \mathrm{~min}$ ). 
The high degradation efficiency in this study may be due to the Al-doped $\mathrm{ZnO}$ sample contains numerous amounts of structural defect on their surface, especially oxygen vacancies. The structural defect at $\mathrm{ZnO}$ acted as the capture center to trap the photogenerated electrons; hence, the recombination of photogenerated excitons could be reduced (Hu et al. 2018).

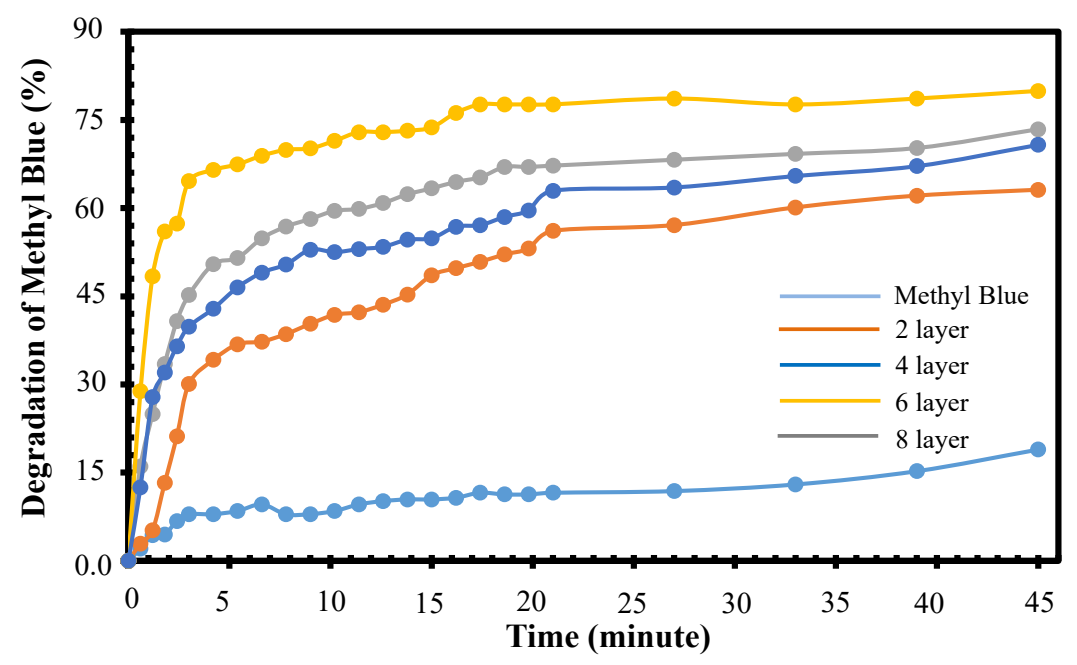

FIGURE 5. Photocatalytic activity of Al-doped $\mathrm{ZnO}$ thin film for the degradation of methyl blue

The experimental result might be ascribed to the following reason. The high intensity of the sample in UV light region allows $\mathrm{ZnO}$ sample to absorb more photoexcited electron and whole which then would break the chemical bond of methyl blue solution and subsequently allows $\mathrm{ZnO}$ catalysts rapidly to degraded methyl blue solution. Besides, the usability of $\mathrm{ZnO}$ photocatalysts is not only determined through their photosensitivity to absorb light but also their ability to overcome some of their intrinsic problems such as fast charge recombination and serious photocorrosion. The highest PL emission in visible light spectrum parallel with the formation of structural defect in $\mathrm{ZnO}$ lattice especially defect from oxygen vacancies and acted as the capture center to trap the photogenerated electrons; hence, the recombination of photogenerated excitons could be hindered. Furthermore, the incorporation of ion $\mathrm{Al}^{+3}$ in $\mathrm{ZnO}$ lattice can led to narrowing the band gap energy value of the sample and allow more charge carrier to involve in photocatalytic reaction (Islam et al. 2019).

\section{CONCLUSION}

The bilayers effect of Al-doped $\mathrm{ZnO}$ thin film on their optical properties and photocatalytic activity of $\mathrm{ZnO}$ under UV light illuminations was explored. The deposition of Al-doped $\mathrm{ZnO}$ with different number of layers was found manipulated the optical properties and crystal structural of $\mathrm{ZnO}$ sample. The optical absorption spectra of the Al-doped $\mathrm{ZnO}$ thin film increase as the number of layers increased. Meanwhile, the lowest emission peaks intensity in visible light spectrum indicates the sample contain lots of structural defect and excess oxygen site on the surface. The best photocatalytic activity was observed with 6 layers of Al-doped $\mathrm{ZnO}$ thin film within $45 \mathrm{~min}$ of exposure to UV light illumination. This confirmed that thicker Al-doped $\mathrm{ZnO}$ deposited in glass substrate shows better photocatalytic activity compared to the thin $\mathrm{ZnO}$. The enhancement of photocatalytic activity can be explained on the basis of reduction of charge carrier recombination rate due to trap charge state creation and narrowing the band gap. This study may open a versatile route to achieving high efficiency of photocatalytic activity of $\mathrm{ZnO}$.

\section{ACKNOWLEDGEMENTS}

This research was financially supported by Hibah Penelitian Unggulan Perguruan Tinggi (Tinggi (No. 25/ E1/KPT/2020) from the Ministry of Research, Technology and Higher Education, Indonesia. This work was also funded by Universiti Kebangsaan Malaysia (UKM) under research grant FRGS/1/2019/STG02/UKM/02/1. 


\section{REFERENCES}

Ahmad, I. 2020. Comparative study of metal (Al, Mg, Ni, $\mathrm{Cu}$ and $\mathrm{Ag}$ ) doped $\mathrm{ZnO} / \mathrm{g}-\mathrm{C}_{3} \mathrm{~N}_{4}$ composites: Efficient photocatalysts for the degradation of organic pollutants. Separation and Purification Technology 251: 117372.

Ameur, S.B., BelHadjltaief, H., Duponchel, B., Leroy, G., Amlouk, M., Guermazi, H. \& Guermazi, S. 2019. Enhanced photocatalytic activity against crystal violet dye of $\mathrm{Co}$ and $\mathrm{In}$ doped $\mathrm{ZnO}$ thin films grown on PEI flexible substrate under UV and sunlight irradiations. Heliyon 5(6): e01912.

Ariffin, M., Roza, L. \& Fauzia, V. 2019. Bayberry-like Pt nanoparticle decorated $\mathrm{ZnO}$ nanorods for the photocatalytic application. Results in Physics 15: 102678.

Bhujbal, P.K., Pathan, H.M. \& Chaure, N.B. 2020. Temperature dependent studies on radio frequency sputtered Al doped $\mathrm{ZnO}$ thin film. Engineered Science 10: 58-67.

Bora, T., Sathe, P., Laxman, K., Dobretsov, S. \& Dutta, J. 2017. Defect engineered visible light active $\mathrm{ZnO}$ nanorods for photocatalytic treatment of water. Catalysis Today 284: 11-18.

Doan, Q.K., Nguyen, M.H., Sai, C.D., Pham, V.T., Mai, H.H., Pham, N.H., Bach, T.C., Nguyen, V.T., Nguyen, T.T., Ho, K.H. \& Tran, T.T. 2020. Enhanced optical properties of $\mathrm{ZnO}$ nanorods decorated with gold nanoparticles for self cleaning surface enhanced raman applications. Applied Surface Science 505: 144593.

Gusain, R., Kumar, N. \& Ray, S.S. 2020. Recent advances in carbon nanomaterial-based adsorbents for water purification. Coordination Chemistry Reviews 405(4): 213111.

Hu, P., Chen, C., Song, J. \& Tang, Z. 2018. Efficient visible-light photocatalysis of ZIF-derived mesoporous $\mathrm{ZnFe} 2 \mathrm{O} 4 / \mathrm{ZnO}$ nanocomposite prepared by a two-step calcination method. Materials Science in Semiconductor Processing 77: 40-49.

Islam, M.R., Rahman, M., Farhad, S.F.U. \& Podder, J. 2019. Structural, optical and photocatalysis properties of sol-gel deposited Al-doped $\mathrm{ZnO}$ thin films. Surfaces and Interfaces 16: 120-126.

Mao, Z., Fu, C., Pan, X., Chen, X., He, H., Wang, W., Zeng, Y. \& Ye, Z. 2020. Raman-based measurement of carrier concentration in n-type $\mathrm{ZnO}$ thin films under resonant conditions. Physics Letters A 384(7): 126148.

Nasrollahzadeh, M., Sajjadi, M., Iravani, S. \& Varma, R.S. 2021. Green-synthesized nanocatalysts and nanomaterials for water treatment: Current challenges and future perspectives. Journal of Hazardous Material 401: 123401.

Palit, S. 2019. Nanomaterials for industrial wastewater treatment and water purification. Handbook of Ecomaterials 1: 195-235.

Putri, N.A., Fauzia, V., Iwan, S., Roza, L., Umar, A.A. \& Budi, S. 2018. Mn-doping-induced photocatalytic activity enhancement of $\mathrm{ZnO}$ nanorods prepared on glass substrates. Applied Surface Science 439: 285-297.
Rahman, M.Y.A., Umar, A.A., Roza, L., Samsuri, S.A.M., Salleh, M.M., Iwantono, I. \& Tugirin, T. 2015. Effect of growth solution concentration on the performance of boron doped $\mathrm{ZnO}$ dye-sensitized solar cell (DSSC). Journal of New Materials for Electrochemical Systems 18(4): 184-249.

Roza, L., Febrianti, Y., Iwan, S. \& Fauzia, V. 2020. The role of cobalt doping on the photocatalytic activity enhancement of $\mathrm{ZnO}$ nanorods under UV light irradiation. Surfaces and Interfaces 18: 100435.

Roza, L., Rahman, M.Y.A., Umar, A.A. \& Salleh, M.M. 2016. Multi-cycle growth of boron doped $\mathrm{ZnO}$ films as photoanode for dye-sensitized solar cell (DSSC). International Journal of Electrochemical Science 11: 1096510977.

Roza, L., Rahman, M.Y.A., Umar, A.A. \& Salleh, M.M. 2015. Direct growth of oriented $\mathrm{ZnO}$ nanotubes by self-selective etching at lower temperature for photo-electrochemical (PEC) solar cell application. Journal of Alloys and Compounds 618: $153-158$.

Vanitha, M., Joni, I.M., Camellia, P. \& Balasubramanian, N. 2018. Tailoring the properties of cerium doped zinc oxide/ reduced graphene oxide composite: Characterization, photoluminescence study, antibacterial activity. Ceramics International 44: 19725-19734.

Wang, Y., Ge, S., Cheng, W., Hu, Z., Shao, Q., Wang, X., Lin, J., Dong, M., Wang, J. \& Guo, Z. 2020. Microwave hydrothermally synthesized metal-organic framework-5 derived C-doped $\mathrm{ZnO}$ with enhanced photocatalytic degradation of Rhodamine B. Langmuir 36(33): 9658-9667.

\section{Liszulfah Roza*}

Program Studi Pendidikan Fisika

Fakultas Keguruan dan Ilmu Pendidikan

Universitas Muhammadiyah Prof. Dr. Hamka

Jakarta Timur

Indonesia

\section{Vivi Fauzia \\ Departemen Fisika \\ Fakultas MIPA \\ Universitas Indonesia \\ Depok 16424 \\ Indonesia}

Mohd. Yusri Abd. Rahman

Institute of Microengineering and Nanoelectronics (IMEN)

Universiti Kebangsaan Malaysia

43600 UKM Bangi, Selangor Darul Ehsan

Malaysia

*Corresponding author; email: liszulfahroza@uhamka.ac.id

Received: 21 August 2020

Accepted: 31 August 2020 